\title{
Hymenopteran fauna inhabiting K.T.H.M. College Campus, Nashik, Maharashtra
}

*Sachin Arjun Gurule, Tushar Ananda Jadhav and Jyoti Haribhau Gangurde

\author{
Department of Zoology, \\ MVP's K.T.H.M. College, \\ Gangapur Road, NASHIK 422002. \\ *Corresponding Author \\ E-mail:sachin.gurule@yahoo.com
}

Received : 28.02.2020; Accepted : 22.04.2020

\begin{abstract}
Inventory of wasps, bees and carpenter bees belongs to order hymenoptera was prepared by collecting naturally dead specimens from KTHM College campus, Nashik during the July 2015 to February 2016. In the present study 25 species belonging to 19 genus and 11 families of Hymenoptera have been recorded. Of which total 11 species identified upto species level and remaining given morpho-species Genus (sp.) label. The identification of species was done by following keys of existing literature and confirmed by comparing the specimens in collection department of Bombay Natural History Society (BNHS), Mumbai. Family apidae and vespidae found to be dominating families. Dominance of four species Apis dorsata, $A$. cerena indica, Thyrus ramosus, Amegila sp. was observed in terms of population, due to plentiful nector yielding plants in the college campus. The families Xylocopidae and Sphecidae were represented by 3 species each. Families Chrysididae, Ichneumonidae and Braconidae were represented by single Stibum sp., Coelichmeumon sp. and Cremnops sp. respectively.

Figures : 02

References : 33

Table : 01

KEY WORDS : Bees, Carpenter bees, Diversity, Hymenoptera, KTHM College, Nashik, Wasps.
\end{abstract}

\section{Introduction}

Class insecta is dominated by four insect orders i.e. Coleoptera, Lepidoptera, Hymenoptera and Lepidoptera $^{31}$ and are dominating life forms on planet Earth, providing important ecosystem services viz. herbivory, decomposition, pollination, prarasitism and biocontrolling agents etc. ${ }^{11,33}$. It is well known fact that hymenopteran bees and angiospermic plants evolved together representing the example of coevolution. Among the insects hymenopteran members are well known for pollination and parasitism which is beneficial for plant community. Entomophilous pollination by hymenopteran insects like bees and bumble bees assist plants in their reproduction on one hand and parasitic wasps and ichneumon flies parasitizes the eggs and larvae of phytophagous lepidopteran pest of plants on the other side.

Hymenoptera order comprises the minute to medium sized insects such as bees, wasps, carpenter bees, ichneumon flies, saw flies, termites and ants. In case of adults of bees, wasps, carpenter, bumble bees possess a pair of membranous wings with the reduced venation, smaller hind wings often provided with hamulate wing coupling. Thoracic legs variously modified specially in bees imparting different function. Mouth parts chiefly adapted for chewing and lapping, biting and sucking, moulding wax or collecting mud (mudwasps). The abdomen usually basally constricted and its first segment fused with the metathorax; an ovipositor always present and modified for sawing, piercing or stinging ${ }^{31}$.

On the basis of morphology, Hymenoptera divided into two suborders viz. Apocrita and Symphyta and consists of more than $1,00,000$ described species which contain some of the most advanced and specialized insects. Hymenoptera divided into two suborders Symphyta consisting primitive hymenoptera such as saw flies and Apocrita consisting highly evolved hymenoptera such as wasps, ants, bees. Suborder Apocrita is larger

ACKNOWLEDGEMENTS : The authors are thankful to Dr. V.B. Gaikwad, Principal, K.T.H.M. College, Nashik for giving permission to carry out the present work. We are equally thankful to former head Dr. P.R. Bhamre and present head Dr. V.R. Kakulte for supporting and providing laboratory facilities in the Zoology department. We express our sincere thanks to Mr. Rahul Khot, Collection Department, Bombay Natural History Society (BNHS), Mumbai for providing confirmation of identified specimens. Finally, we are grately indebted to UGC and DBT who have sanctioned the funds for basic instrumentation facility in the department of Zoology, K.T.H.M. College, Nashik. 
TABLE-1: Checklist of bees, wasps, bumble bees recorded from K.T.H.M. College campus

\begin{tabular}{|c|c|c|}
\hline Superfamily & Sr. No. & Taxon \\
\hline \multirow[t]{12}{*}{ Apoidea } & A) & Family Apidae \\
\hline & 1 & Apis dorsata \\
\hline & 2 & Apis cerena indica \\
\hline & 3 & Thyreus ramosus \\
\hline & 4 & Amegilla sp. \\
\hline & B) & Family: Megachilidae \\
\hline & 5 & Megachile sp. \\
\hline & 6 & Megachile lanata \\
\hline & C) & Family: Xylocopidae \\
\hline & 7 & Xylocopa sp. A \\
\hline & 8 & Xylocopa sp. B \\
\hline & 9 & Xylocopa sp. C \\
\hline \multirow[t]{8}{*}{ Vespoidea } & D) & Family: Vespidae \\
\hline & 10 & Vespa orientalis \\
\hline & 11 & Delta conoideum \\
\hline & 12 & Delta pyriforme \\
\hline & 13 & Ropalidia marginata \\
\hline & E) & Family: Eumenidae \\
\hline & 14 & Rhynchium sp. \\
\hline & 15 & Eumenes sp. \\
\hline \multirow[t]{6}{*}{ Scolioidea } & F) & Family: Scolidae \\
\hline & 16 & Scolia sp. A \\
\hline & 17 & Scolia sp. B \\
\hline & G) & Family: Mutilidae \\
\hline & 18 & Trogaspidia sp. \\
\hline & 19 & Timulla sp. \\
\hline
\end{tabular}




\begin{tabular}{l|l|l}
\hline \multirow{2}{*}{ Superfamily } & Sr. No. & Taxon \\
\hline \multirow{2}{*}{ Sphecoidea } & H) & Family: Sphecidae \\
\cline { 2 - 3 } & 20 & Chalybion bengalense \\
\cline { 2 - 3 } & 21 & Sceliphron caementarium \\
\cline { 2 - 3 } & 22 & Ammophila sabulosa \\
\hline \multirow{2}{*}{ Bethyloidea } & I) & Family : Chrysididae \\
\cline { 2 - 3 } & 23 & Stilbum sp. \\
\hline \multirow{2}{*}{ Ichneumonoidea } & J) & Family: Ichneumonidae \\
\cline { 2 - 3 } & 24 & Coelichmeumon sp. \\
\cline { 2 - 3 } & K) & Family : Braconidae \\
\cline { 2 - 3 } & 25 & Cremnops sp. \\
\hline
\end{tabular}

and divided into two divisions of the Parasitica embodying parasitic forms and Aculeata bearing solitary stinging forms. Similarly Symphyta is divided into two divisions viz. Strophandria bearing only Tenthredionoidea and Orthandria bearing rest of the families of sawflies. There are over twenty one superfamilies and seventy two families recognised from above mentioned groups ${ }^{25}$. They may be free-living, phytophagous, predatory, entomophagous parasitic or social insects ${ }^{31}$. Certain wasp, bees and ants are polymorphic and social insects. Trophallaxis or mutual exchange of food between adults and larvae, is common among behaviour, habits, nest buildings, caste system, chemical communication system etc. ${ }^{31}$.

Fabricius are studied in Indian Hymenoptera in 1775. The significant work on Indian hymenopteran fauna was carried out ${ }^{5,6,7}$ and produced magnificent classical publication entitled 'Fauna of British India'. Then after valuable knowledge regarding hymenopteran was contributed by many workers ${ }^{1-3,8-10,13-14,17-20,29-30,32}$ who studied the potter and hairy wasps of family Scolidae from Andhra Pradesh. Some workders ${ }^{23}$ reported 181 species of ichneumonids belongs to 55 genera \& 13 subfamilies from Maharashtra. Diversity and distribution pattern of hymenopteran insect in Jorhat district of Assam was studied ${ }^{24}$ wherein 50 species belong to 42 genera and 21 families were reported. Potter wasps was reported from Arunachal Pradesh ${ }^{26}$ and hairy wasps from Andhra Pradesh ${ }^{15}$. The present inventory of hymenoptera is the first attempt for this study area.

\section{Material and Methods}

The K.T.H.M. College is reputed College in Nashik city and has green campus having the total area about 37 acres and located near basin on Godavari river. Boundary of college campus has significant greenary due to setup of botanical garden, river basin and agricultural fields that attract many insects in the campus.

The collection of naturally dead wasps and bees were undertaken in K.T.H.M. College campus to assess diversity of hymenoptera. Collected dead specimens were brought to the laboratory, pinned using entomological pins of size No. 00, 3; and preserved dry using electric oven at $30-45^{\circ} \mathrm{C}$ following standard method 27,28 . The dried speciemens were labelled and stored in insect boxes and napthalene ball were kept to prevent attack of pests.

Identification of preserved specimens has been carried out by following identification keys of existing literature. The identification was accomplished by observing diagnostic characters in a series of alternate choices with the help of published keys $s^{4-7,10,12,27}$ and available online sources such as India Biodiversity portal, Hymenoptera forum etc. Further identification of collected specimen was confirmed by comparing the specimens available in collection department of 'Bombay Natural History Society' (BNHS), Mumbai.

\section{Result and Discussion}

The present investigation helped to prepare inventory of hymenopteran diversity within K.T.H.M. 


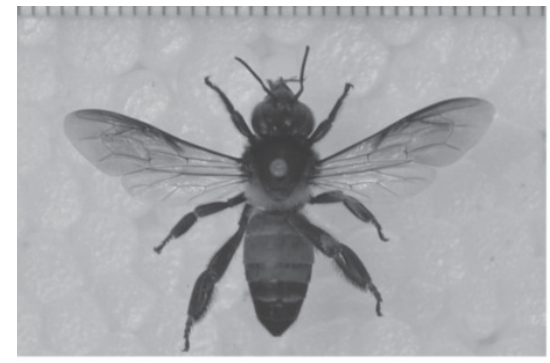

1. Apis dorsata

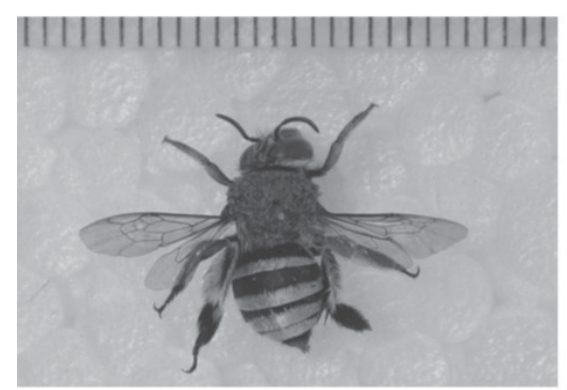

4. Amegilla sp.

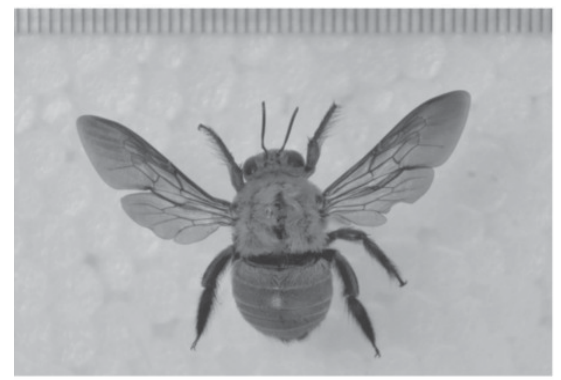

7. Xylocopa sp. A

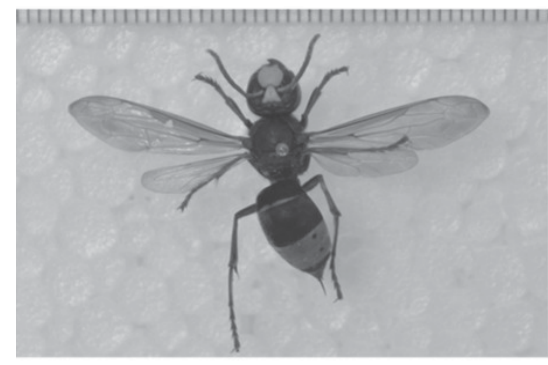

10. Vespa orientalis

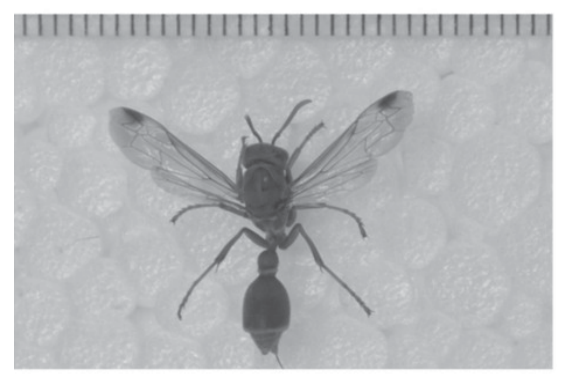

13. Ropalidia marginata

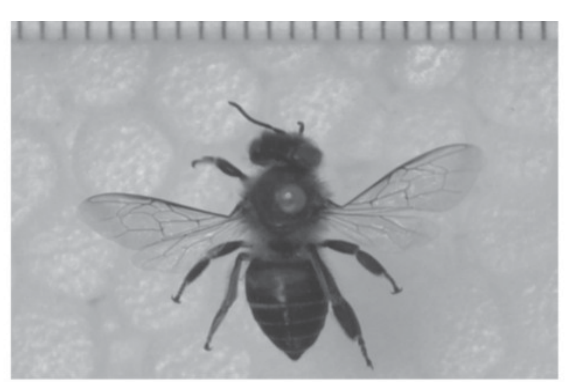

2. Apis cerena indica

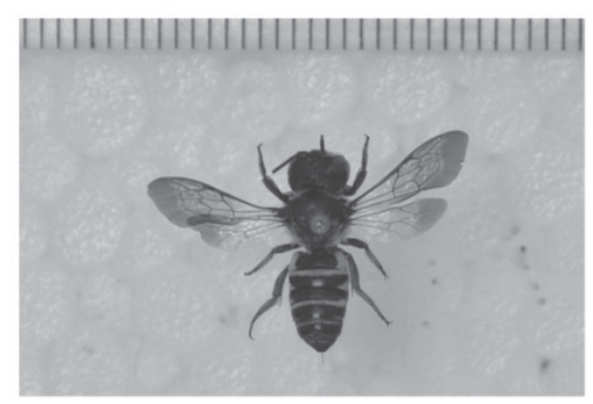

5. Megachile sp.

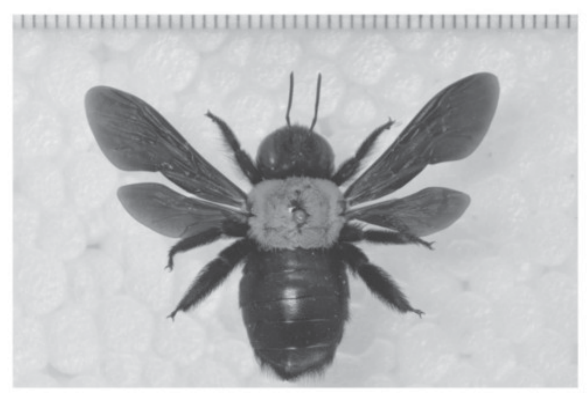

8. Xylocopa sp. B

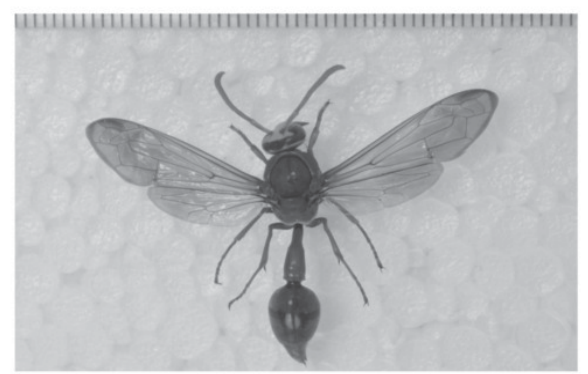

11. Delta conoideum

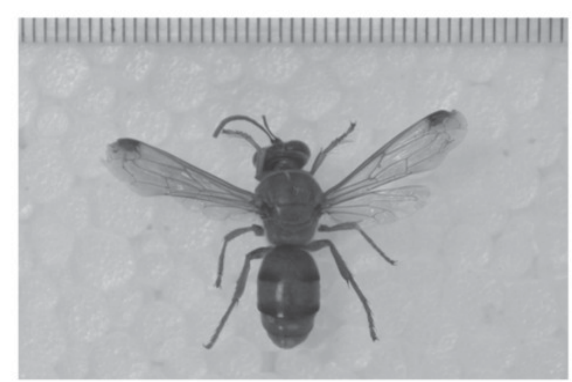

14. Rhynchium sp.

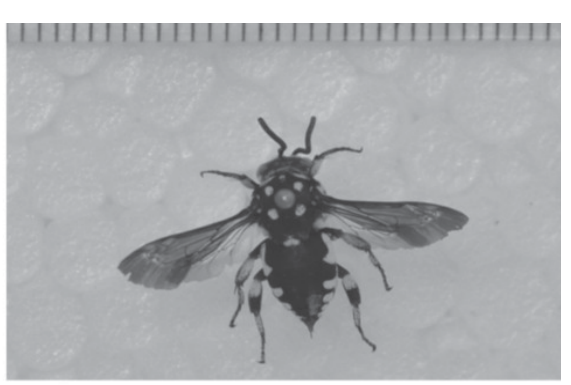

3. Thyreus ramosus

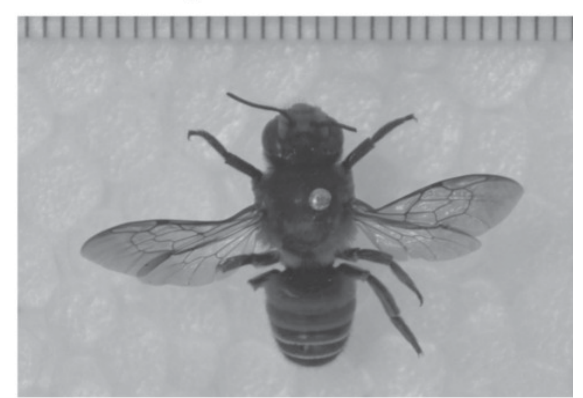

6. Megachile lanata

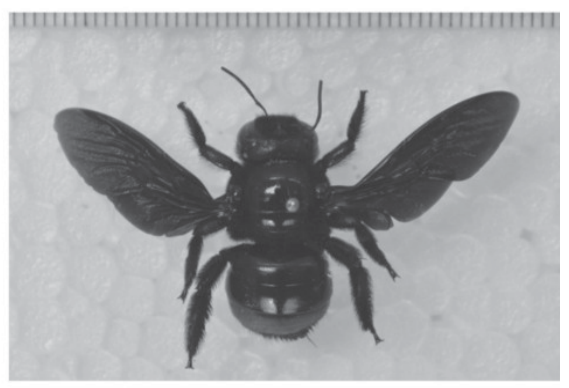

9. Xylocopa sp. C

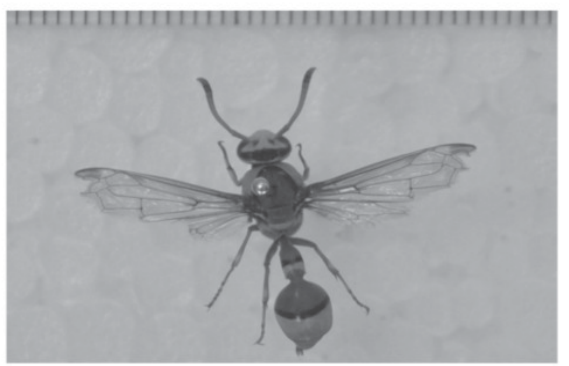

12. Delta pyriforme

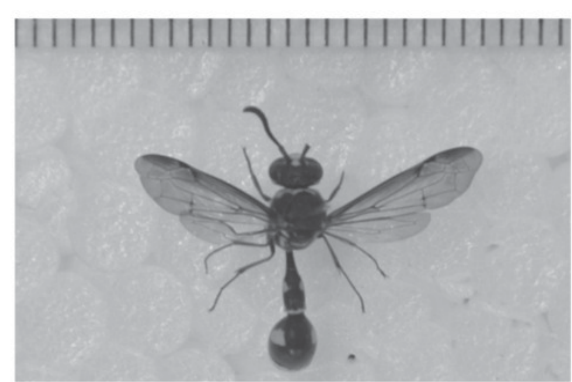

15. Eumenes sp.

Fig. 1 : Hymenopteran insects belonging to families Apidae, Megachilidae, Xylocopidae, Vespidae and Eumenidae 


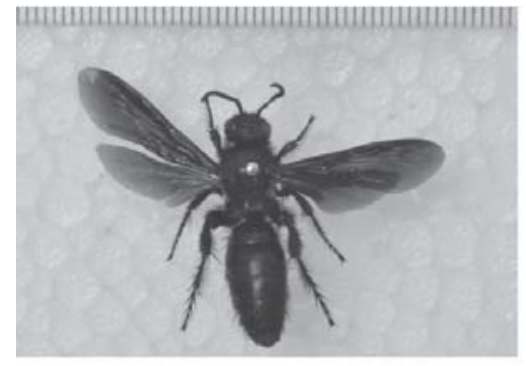

16. Scolia sp. A

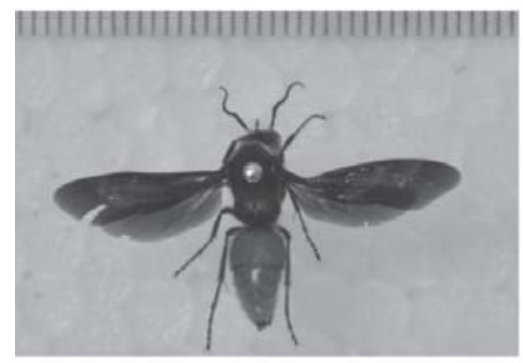

19. Timulla sp.

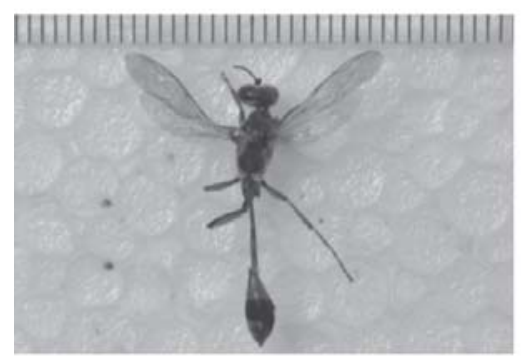

22. Ammophila sabulosa

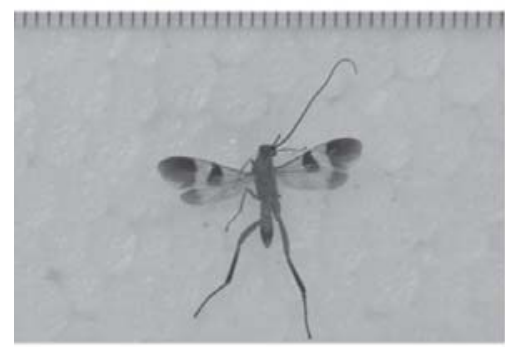

25. Cremnops sp.

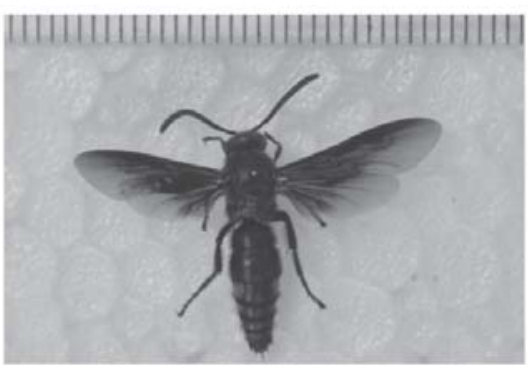

17. Scolia sp. B

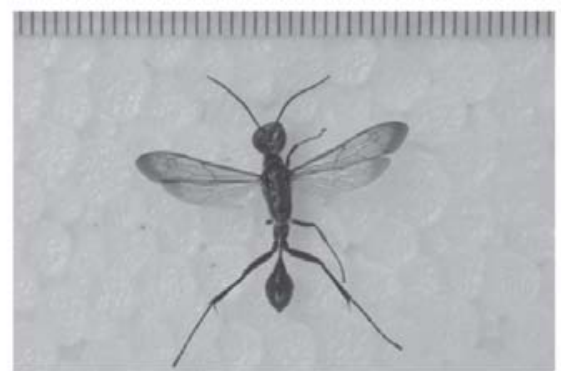

20. Chalybion bengalense

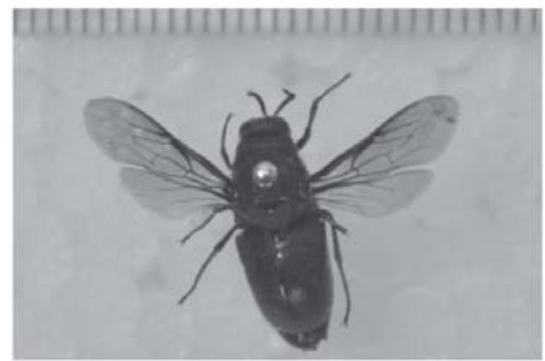

23. Stilbum sp.

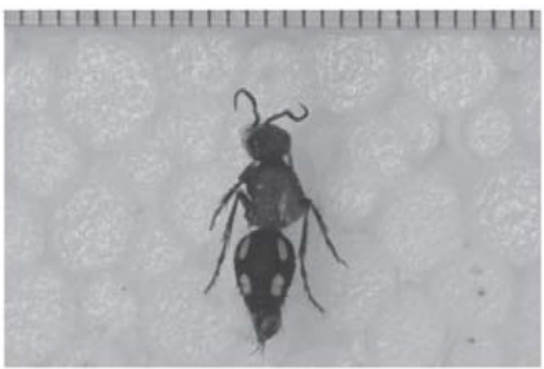

18. Trogaspidia sp.

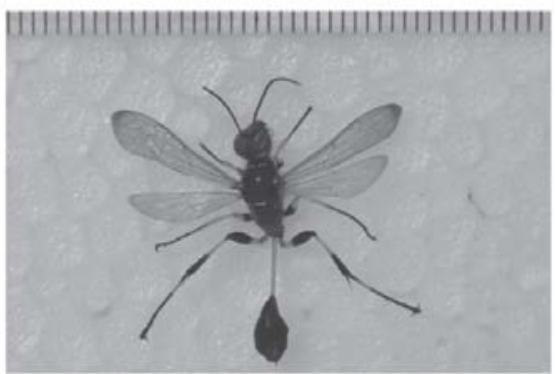

21. Sceliphron caementarium

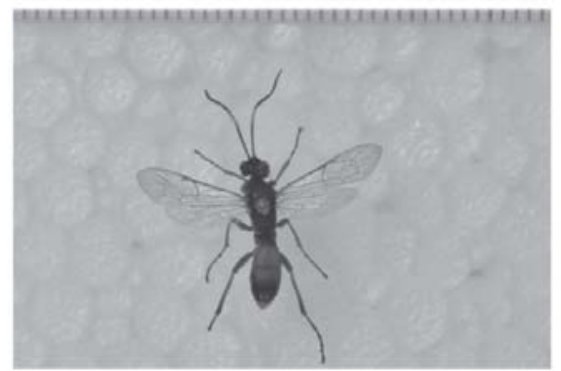

24. Coelichmeumon sp.

Fig. 2 : Hymenopteran insects belonging to families scolidae, Mutilidae, Sphecidae, Chrysididae, Ichneumonidae and Braconidae

College campus and yield 25 species. Checklist of hymenoptera in the given study area represent 6 superfamiles viz. Apoidea, Vespoidea, Scolioidea, Sphecoidea, Bethyloidea and Ichneumonoidea. Total 25 hymenopteran species pertaining to 19 genera, 11 families and 6 superfamilies were identified and family apidae was found to be dominating. The field observation within campus found the dominance of four species of bees viz. Apis dorsata, Apis cerena indica, Thyrus ramosus and
Amegila sp. which may be due to rich plantation of nectar yielding plants within the campus and nearby agricultural fields acting as source of pollens. Four species recorded from family Vespidae and three species each recorded from families Xylocopidae and Sphecidae; two species each were found from family Megachilidae, Eumenidae, Scolidae and Mutilidae while only single species each recorded from Chrysididae, Ichneumonidae and Braconidae families. The hymenopteran species 
composition and taxon recorded during the present study is listed in Table-1 and plates 1 \& 2 .

Workers ${ }^{3}$ reported 82 hymenopteran species from 47 genera and 17 families from Amba Reserve Forest of Maharashtra; in comparison with this in the present study only 25 species recorded may be due to short time study in comparatively small area that lies in the center of city with lack of forest vegetation that harbors huge insect diversity. Workers ${ }^{21-23}$ have recorded four new species of Ichneumonidae reported 181 species from Ichneumonidae. In the present study only single species belonging to family Ichneumonidae was encountered may be due to lack of use to malaise trap for their collection as mentioned ${ }^{23}$ and reported forty five species of bees from families Anthophoridae, Apidae, Collectidae, Halictidae and Megachilidae from tropical lowland forests of South-East Asia while in the present study only 4 species of bees from family Apidae and 2 species of bees from family Megachilidae were recorded. From the present results it is concluded that the area has moderate diversity of hymenopteran insects but needs detailed and long term study to explore the fauna.

\section{References}

1. Abdurahiman UC, Joseph KJ. Contribution to our knowledge of fig insects (Chalcidoidea: Parasitic Hymenoptera) from India. Oriental Insects. 1967a; 1(1-2): 1-19.

2. Abdurahiman UC, Joseph KJ. New fig insects (Hymenoptera: Chalcidoidea) from India: Three Torymids parasitic on Agaonids. Entomophaga. 1967b; 20(1): 73-80.

3. Aland SR, Mamlayya AB, Gaikwad SM, Bharmal DL, Bhawane GP. Diversity of insects with special reference to order hymenoptera in Amba reserved forest of Kolhapur district, Western ghats, Maharshtra, India. Biological forum An Int. Journal. 2010; 2(2): 59-64.

4. Atwal AS, Dahiwal GS. Agricultural pests of south Asia and their management, Kalyani publishers. 2010.

5. Bingham CT. The Fauna of British India including Ceylon and Burma. Hymenoptera- Vol. I Waps and Bees, (Ed.) W.T. Blanford Today and Tomorrows Printers and Publishers. 1975a. 1-579.

6. Bingham CT. The Fauna of British India including Ceylon and Burma. Hymenoptera-Vol. II Ants and CuckoWaps, (Ed.) W. T. Blanford. Today and Tomorrows Printers and Publishers. 1975b; 1-505.

7. Bingham CT. Hymenoptera Vol. II Ants, Cuckoo Wasps. In: The Fauna of British India including Ceylon and Burma, Blanford, W.T. (ed.). Taylor and Francis, London. 1903.

8. Gupta A, Pereira B, Churi PV. Illustrated notes on some reared parasitic wasps (Braconidae: Microgastrinae) with new host and distribution records from India along with reassignment of Glyptapanteles aristolochiae (Wilkinson) as a new combination. Entomological News. 2011; 122: 451-468.

9. GuptaA, Pereira B. Anew species of Glyptapanteles (Hymenoptera: Braconidae: Microgastrinae), a larval parasitoid of Elymnias hypermnestra (Linnaeus) (Lepidoptera: Nymphalidae), along with some new host records of parasitoids from Peninsular India. Zootaxa. 2012; 3227: 54-63.

10. Gupta SK, Johnathan JK. Fauna of India and adjacent countries, Hymenoptera: Scolidae, Published by the director, Zool. Surv. India, Kolkata. 2003; 1-277.

11. Gurule SA. Taxonomic Study of Moth from North Maharashtra, India. Ph.D. Thesis submitted to Savitribai Phule Pune University, Pune. 2013; 1-7.

12. Hook P. A concise guide to insects, paragon Book Ltd., Queen street, Bath BAI. IHE. 2008.

13. Joseph KJ, Narendran TC, Joy PJ. Redescription of three Oriental species of Brachymeria Westwood (Hymenoptera: Chalcididae). Mysore Journal of Agriculture Sciences. 1973a; 7: 302-309.

14. Joseph KJ, Narendran TC, Joy PJ. Oriental Brachymeria (Hymenoptera: Chalcididae). Zoological Monograph No. 1 1973b; 1-215.

15. Kumar Girish P. Taxonomic notes on hairy wasp of Andhra Pradesh, India. Rec. zool. Surv. India. 2009; 109 (Part-I): 97-103.

16. Liow LH, Sodhi NS, Elmquist T. Bee diversity along a disturbance gradient in tropical lowland forests of SouthEast Asia. Journal of Applied Ecology. 2001; 38: 180-192. 
17. Narendran TC, Sheela S. A new species and key to species of Mesocomys Cameron (Hymenoptera: Eupelmidae). Journal of Ecobiology. 1995; 7(4): 307-311.

18. Narendran TC, Suresh PM. Three new species of Palachia (Torymidae) described. Hexapoda. 1989; 1: 45-53.

19. Narendran TC. A new species of the interesting genus Rhynchochalcis Cameron (Hymenoptera: Chalcididae) From India. Current Science. 1986; 55(11): 544-546.

20. Narendran TC. A new species of Riekisura Boucek (Hymenoptera: Pteromaliae) From India. Journal of Advanced Zoology. 1992; 13(1 \& 2): 57-58.

21. Nikam SM, Desai AE. Two new species of Budias Cameron (Ichneumonidae : Mesosteninae) from India, Indian Journal of Entomology. 2008; 70(2): 172-175.

22. Nikam SM, Desai AE. Discovery of polysphinctini genus Eruga Town Es (Hymenoptera : Ichneumonidae) from the Orient. Geobios. 2009; 36(1): 141-144.

23. Nikam SM, Kharat AJ. Insecta : Hymenoptera : Ichneumonidae. Fauna of Maharashtra, State Fauna series, Zoological Survey of India. 2012; 20(Part 2): 627-636.

24. Rajkumari P, Sharma D, Rahman A, Patgiri P. Diversity and Distribution pattern of hymenoptera insect in Jorhat District, Assam, India. International Journal of Science and Research. 2014; 3: 1938-1941.

25. Richards et al. Evolutionary significance of photoreceptors, In Retroficanct. The society for Investigative and comparative Biology. 1977; 647-653.

26. Shrinivasan G, Kumar GP. New records of potter wasps (Hymrnoptera: Vespidae: Eumeninae) from Arunachal Pradesh, India: Five genera and ten species. Journal of Threatened Taxa. 2010; 2(12): 1313-1322.

27. Shrivastava KP. Collection and preservation of insect and classification and consideration for life Histories", A text books of applied entomology, II. 2004; 36-64.

28. Singh R, Sachan. Elements of Entomology", Rastogy Publication. 2004; 27-70.

29. Sudheendrakumar VV. A report on the Ichneumonid parasites of Hyblaea puera recorded from Nilambur, Kerala. Journal of Tropical forestry. 1990; 6(1): 102-103.

30. Sudheendrakumar VV. Notes on hymenopteran parasites of Eutectona machaeralis recorded from Nilambur, Keral. The Indian Forester. 1993; 119(6): 510-511.

31. Tembhare DB. Modern Entomology. Published by Himalayan Publishing house, Mumbai. 1997; 1: 407-422.

32. Tsing- Chao ma, Daw- Tsuen. The Indian species of the genus Xylocopa (Hymenoptera) from the laboratories of zool. Survey of India, Kolkata. 1988; 114/88.

33. Weisser W, Siemann E. Insects and ecosystem function. Springer-Verlag, Berlin. 2004. 